that it was denying preferential tariff treatment for four South African imports.

South Africa's new health minister, Manto Tshabalala-Msimang, told Nature that the law is meant to address the "legacy of apartheid". "We don't want to interfere with the patent rights, but we want to get drugs of quality at a price we can afford," she says.

"Why would you want to buy the drug at SAR80 (US\$13) when if you import it you would get it at SAR30?" she asks. "In situations of emergency, what do you do? This is the question I would pose to PMASA."

Nonetheless, she says, she is making it "very high on my priority list" to meet the drug makers. She says the government is willing to negotiate the implementation of the law "in such a way that it meets the needs of the pharmaceutical industry".

That will take some doing, according to the drug companies. "This is a major issue," says Jeff Trewhitta, spokesman for Pharma. "The cost of research is very high. Patent protection is the lifeblood of the industry."

Mirryena Deeb, chief executive officer of PMASA, says the law is so broad that it "undermines the patent law system" and allows the health minister to "just take away the patent right".

An official at the office of the US Trade Representative (USTR), which has aggressively lobbied South Africa to reverse the law, calls it "offensive". "They've decided that the way to solve the [AIDS] problem is to deny intellectual property rights."

The USTR, Gore and the drug groups argue that the law breaches an important World Trade Organization (WTO) agreement on trade-related aspects of intellectual property protection, the 'TRIPS' agreement.

But Gore's critics read the agreement as allowing precisely the kind of action South Africa has taken. The agreement says compulsory licensing is permitted in cases of "national emergency or extreme urgency".

Some observers say that the TRIPS language is sufficiently ambiguous for there to be honest disagreement on whether South Africa is in breach of it. What angers some, says one international health official, is that "commercial interests are leading [the US government to use] pressure tactics", rather than using WTO dispute mechanisms.

According to a State Department report presented to Congress in February, Gore, the USTR, the Department of Commerce and the State Department have mounted an "assiduous, concerted campaign" to overturn the South African law.

Some argue that the issue goes beyond patent rights. Tom Coates, director of the AIDS Research Institute at the University of California, San Francisco, warns of the danger of drug resistant viral strains developing if the drugs are not imported in the right combinations and quantities, and administered with proper oversight. MeredithWadman

\title{
Chlorine industry says EPA rules ignore good science
}

[WASHINGTON] The US Environmental Protection Agency (EPA) is being taken to court by the Chlorine Chemistry Council, a Washington-based group representing chlorine manufacturers and users. The case could determine not only how the agency assesses cancer risks, but how it weighs scientific evidence in crafting regulations.

A federal court will hear arguments next year charging that the EPA failed to use the best available scientific information when it set goals for the maximum amount of chloroform allowed in drinking water.

Chloroform, the most common chemical by-product of water disinfection, causes cancer in laboratory animals when administered at very high doses. The scientific issue concerns whether there is a dose below which chloroform is safe.

EPA guidelines for assessing cancer risk extrapolate linearly the harmful effects seen at high doses, so that any dose is considered harmful. But a non-zero safe 'threshold' could theoretically be set if enough were known about a chemical's mode of action.

The controversy over chloroform began in March 1998, when the agency released new data on disinfection by-products, and announced that it was considering changing the goal for chloroform contamination in drinking water from zero to 300 milligrams per litre - the first acknowledgement of a threshold dose for a regulated carcinogen.

But in last December's final ruling, the agency retreated from this position, and set the goal at zero. The Chlorine Chemistry Council, water utilities and other groups claimed the agency had buckled to pressure from environmentalists, and filed suit. Complying with the new regulations is estimated to cost industry $\$ 1$ billion a year.

The International Society of Regulatory Toxicology and Pharmacology (ISRTP), which, along with the chlorine council, sponsored a meeting in Washington on the EPA's chloroform policy, said in a statement that there was "no justification for the EPA management's decision to ignore the advice of its own scientists".

Agency scientists conducted an extensive review of chloroform in the five years leading up to the March announcement, considering more than 30 toxicological studies and cosponsoring a 1997 review by the International Life Sciences Institute. Based on that analysis, the EPA concluded that "a nonlinear [threshold] approach is more appropriate for extrapolating low-dose cancer risk than the low-dose linear approach".

Agency scientists involved in the work say they were frustrated, therefore, when the

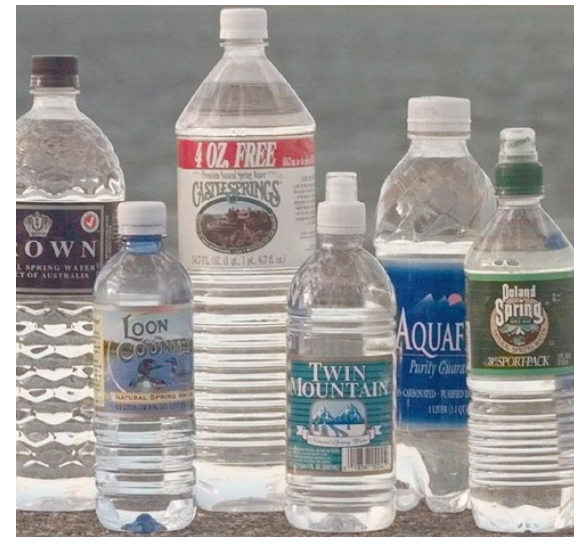

Bottling out: as sales of bottled water rise, court case focuses attention on the safety of tap water.

EPA reverted to the linear approach in its final ruling.

Erik Olson of the Natural Resources Defense Council (NRDC), a Washingtonbased environmental group that opposes a non-zero goal, says the episode reveals "deep divisions" within the agency.

Language in the December ruling bears this out. Calling the zero goal an "interim risk-management decision," the agency said that even though the "underlying science for using a nonlinear extrapolation approach... is well founded," further discussion was needed, as the new approach would represent a "significant and precedential, albeit sound, application of new science to the policy and risk-management decision-making process".

The Chlorine Chemistry Council hopes to exploit that candidness, arguing that the agency has not used the best available peerreviewed science, as laws governing drinking water safety require. Oral arguments will be heard in a federal circuit court in Washington, which recently overturned EPA regulations on air pollution, partly on the basis of inadequate justification.

Olson believes the EPA made the right choice in December, and points out that not all scientists agree that the mode of action for chloroform carcinogenicity is well enough established to end the zero-tolerance policy.

But many toxicologists see the EPA's action as a stalling tactic. "When we have data, the simple use of a default represents a failure," said Jay Goodman, president of the Society of Toxicology.

EPA guidelines for assessing cancer risk have been under review for nine years, and have been further delayed by an additional review to consider children's health. The agency's science advisory board last month urged the EPA to publish the guidelines "as soon as judiciously possible”. Tony Reichhardt 